\title{
An Overview of Vulture Conservation in Nepal
}

\author{
Ishana Thapa ${ }^{1}$
}

\begin{abstract}
Two species of vulture White-rumped Gyps bengalensis and Slender-billed G. tenuirostris are in grave danger of extinction with rapid decline throughout their ranges in Nepal with the complete loss of breeding colonies and local extinctions increasingly taking place. Nepal Government has already banned veterinary drug diclofenac which is the major cause of decline due to poisoning in food supply. Meloxicam has been widely promoted as the safe replacement of Diclofenac. Captive population have been established at Kasara, Chitwan National Park for future reintroduction. To reduce mortality in the wild in situ measures have been initiated through establishment of vulture restaurants as safe feeding sites.

दुई प्रजातिका गिद्धहरु डंगर गिद्ध र सानो खैरो गिद्धको सँख्यामा ठुलो गिरावट आएको तथा ठुलो संख्यामा रहेका धेरै गुँडहरु पनि सखाप भएको हुनाले नेपालवाट यिनीहरु लोप हुने अवस्थामा पुगेका छन्। यस विनाशको कारक तत्व मानिने पशु सेवामा प्रयोग गरिने डाइक्लोफेनेक नामक औषधि, जुन सिनोवाट संक्रमित हुन्छ, त्यस औषधिलाई नेपाल सरकारले निषेधित गरिसकेको छ। यसको सट्टामा हानि रहित वैकल्पिक औषधि मेलोक्सीकेमको प्रयोगलाई प्रोत्साहन गरिएको छ। यसको साथै चितवन राष्ट्रिय निकुन्जको कसरामा केही गिद्धहरुलाई प्रजनन् तथा भविष्यमा प्राकृतिक स्थानान्तरणको लागि राखिएका छन्। प्राकृतिक अवस्थामा नै यिनीहरुको संरक्षणको लागि विभिन्न ठाउँहरुमा सुरक्षित खाना प्रदान गर्ने उद्देश्यले गिद्ध रेष्टुरेन्टहरु स्थापना गरिएका छन् ।
\end{abstract}

Key Words: Critically endangered, Diclofenac, Meloxicam, Conservation, Breeding centre, Vulture restaurant

\section{Introduction}

Three species of vultures in Asia are in grave danger of extinction across the Indian subcontinent. Populations of White-rumped Vulture Gyps bengalensis, Long-billed Vulture G. indicus and Slender-billed Vulture G. tenuirostris have declined by more than $97 \%$ in India (Prakash et al. 2003; Pain et al. 2004) and Pakistan and annual rates of decline appear to be increasing.

In Nepal, rapid declines of White-rumped and Slender-billed Vulture numbers have been documented from various places (Baral et al. 2004). Vultures have declined by the same degree throughout their ranges in Nepal and these declines are continuing, with the complete loss of breeding colonies and local extinctions increasingly taking place. Due to these declines, all three species were listed by IUCN - The World Conservation Union in 2000 as Critically Endangered, which is the highest category of threat. The decline of the vultures was not limited to these three species, in 2007, further two species Red headed Vulture Sarcogyps

${ }^{1}$ Bird Conservation Nepal, Kathmandu, Nepal, Email: ishana@birdlifenepal.org 
calvus and Egyptian Vulture Neophron percnopterus were listed in IUCN red list as critically endangered and vulnerable respectively.

The cause of these declines has been shown to have been caused by the veterinary drug diclofenac (Oaks et al. 2004), which is widely used to treat livestock in Asia. Vultures are exposed to diclofenac by feeding on livestock carcasses which contain residues of this drug. A post-mortem examination of dead birds from India and Nepal also showed the high incidence of diclofenac residues and visceral gout (Shultz et al. 2004). The result of mathematical modeling is consistent with the observed rate of population decline. Models indicate that only a small proportion (one in 130) of carcasses contaminated with lethal levels of diclofenac can cause the observed vulture mortality rate (Green et al. 2004). A great achievement is that meloxicam has been safely tested on vultures and is medically as effective as diclofenac (Swarup et al. 2007). So, promotion of meloxicam in wider scale has already been started. The production and import of diclofenac has been banned in Nepal since August 2006 shortly after the ban in India in May 2006 and the same has been done in Pakistan.

Despite numerous challenges, efforts are ongoing for both in situ and ex situ conservation of these critically endangered vulture species both in Nepal and other range countries. Recently Nepal has also developed vulture action plan (2009-2013).

\section{Conservation breeding centre}

With an aim to establish captive population of critically endangered vultures for the purpose of conservation breeding and subsequent reintroduction to a diclofenac free environment, a captive breeding centre has been established in partnership of Department of National Parks and Wildlife Conservation (DNPWC), National Trust for Nature Conservation (NTNC) and Bird Conservation Nepal (BCN) supported by Royal Society for the Protection of Birds (RSPB, UK) and Zoological Society of London (ZSL, UK). The Vulture Conservation Breeding Centre has been established at Chitwan National Park, Kasara which currently holds 44 White rumped Vultures.

\section{In situ conservation}

With support from RSPB, BCN has been monitoring potential vulture nesting colonies all over Nepal for the last 7 years and has done several community awareness programmes. BCN has also been monitoring veterinary diclofenac and other NSAIDs (Non Steroidal Anti Inflammatory Drugs) in potential areas all over Nepal and where possible swapping of diclofenac with meloxicam is also done.

In order to involve the local communities in conserving the potential vulture nesting colonies, BCN came up with an idea of setting up safe feeding stations as vulture restaurant in these sites. This was first initiated at Pithauli, Nawalparasi in the buffer zone of Chitwan National Park. The project was financially supported by UNDP Small Grants Programme. This is a 
win win situation in which the local communities operate the vulture restaurants to provide safe food for vultures and in return local communities get livelihood benefit from tourism promotion and other income generating activities like sale of the cow skin and bone, vermin composting etc. This has been a very successful project where there is increase in the nest numbers of the colony with the colony at Nawalparasi increasing from 17 to 45 pairs in three years of focused work and the local communities have received economic benefit and are well managing the vulture restaurant.

Popularity of the vulture restaurant has attracted local communities of other areas in establishing the vulture restaurant. Hence, the vulture restaurants have been replicated in Gaidahawa, Rupendehi (supported by Critical Ecosystem Partnership Fund CEPF), Dang (supported by CEPF), Kailali (supported by RSPB and BCN). All these restaurant sites have shown a positive result with increase in nest numbers.

\section{Challenges}

While the current bans on the manufacture of veterinary diclofenac are essential, much remains to be done to ensure that the affected species do not disappear from Nepal and other range countries. Retail sale of veterinary diclofenac is still legal in both Nepal and India. Awareness campaigns, incentives for meloxicam use and a ban on retail sale and use of veterinary diclofenac are likely to be necessary to bring diclofenac contamination of domestic ungulate carcasses down to the very low levels required for the safety of wild vultures. The use on livestock of diclofenac formulated for human use is also a possible barrier to the full removal of diclofenac from vulture food supplies. Adequate monitoring is essential, both of the availability of veterinary diclofenac and its use.

The rapidity of vulture declines and the uncertainty about when diclofenac contamination will be removed make the establishment of conservation breeding centres a continuing necessity. Although small-scale captive breeding efforts have been initiated, genetic diversity estimates, potentially useful in conservation efforts, are presently lacking. Given the overall decline, it is not known to what extent levels of genetic diversity currently exist in the remaining populations. The temporal genetic diversity estimate was carried by Johnson et al. for the last wild White-rumped vulture breeding colony in Pakistan during 2000-2006, and have show with simulations that a much larger captive population size is required than currently maintained to prevent further loss of genetic diversity. Before this species is extinct in the wild, it is crucial that additional individuals are included in the captive population.

\section{Conclusion and Recommendation}

Though the conservation breeding centre and the vulture restaurants have given a ray of hope on conservation of the critically endangered vultures but until and unless a diclofenac free environment is created the vultures will not be safe in the wild. Hence, focus should be 
given on expanding the conservation efforts at vulture restaurants to landscape level through setting up vulture safe zones / diclofenac free zones. Efforts should also be made in supporting other vulture range countries in replicating this initiative and establishing a good network for maximizing the impact of vulture safe zones in vulture conservation.

\section{Acknowledgements}

We are much grateful to the Government of Nepal/Ministry of Forest and Soil Conservation, Department of National Parks and Wildlife Conservation, Department of Forest, Department of Drug Administration, Department of Livestock Services and Nepal Veterinary Association for their strong commitment on vulture conservation. We would like to thank RSPB, ZSL, Darwin Initiative, UNDP/GEF-SGP, CEPF, WWF, and ITNC for the financial support. We are also grateful to NTNC for their strong partnership in vulture conservation. We also appreciate the support of local communities and the media in our effort to conserve the critically endangered vultures.

\section{Reference}

Baral, H. S., Giri, J. B. and Virani, M. Z. 2004. On the decline of Oriental Whitebacked Vultures Gyps bengalensis in lowland Nepal, pp. 215-219. In R. D.Chancellor and B.-U. Meyburg, (ed). Raptors Worldwide. Proceedings of the 6th world conference on birds of prey and owls. Berlin and Budapest: WWGBP and MME/ Birdlife Hungary.

Green, R. E., Newton, I., Shultz, S., Cunningham, A. A., Gilbert, M., Pain, D. J. and Prakash, V. 2004. Diclofenac poisoning as a cause of vulture population declines across the Indian subcontinent. Journal of Applied Ecology 41, 793-800. Green, R. E., Taggart, M. A., Senacha, and K. R. Raghavan,

JeffA. Johnson., Martin Gilbert, Munir, Z. Virani, Muhammad Asim, and David, P. Mindell, Temporal genetic analysis of the critically endangered Oriental White backed Vulture in Pakistan. Biological Conservation. 2008, doi:10.1016/j.biocon.2008.07.001.

Oaks, J.L., Gilbert, M., Virani, M.Z., Watson, R.T., Meteyer, C.U., Rideout, B.A., Shivaprasad, H.L., Ahmed, S., Chaudhry, M.J.I., Arshad, M., Mahmood, S., Ali, A. and Khan, A.A. 2004. Diclofenac residues as the cause of vulture population decline in Pakistan. Nature 427:630 -633. Pain, D.J., Cunnigham, A.A., Donald, and P.F. Duckworth.

Pain, D. J., Cunningham, A. A., Donald, P. F., Duckworth, J. W., Houston, D. C., Katzner, T., Parry-Jones, J., Poole, C., Prakash, V., Round, P. and Timmins, R. 2003. Gyps vulture declines in Asia, temporospatial trends, causes and impacts. Biological Conservation..17: 661-671. 
Prakash, V., Pain, D.J., Cunningham, A.A., Donald, P.F., Prakash, N.,Verma, A., Gargi, R., Sivakumar, S. and Rahmani, A.R. 2003.Catastrophic collapse of Indian whitebacked Gyps bengalensis and long-billed Gyps indicus vulture populations. Biological Conservation 109, 381-390.

Shultz, S., Baral, H.S., Charman, S., Cunningham, A.A., Das, D., Ghalsasi, G.R., Goudar, M.S., Green, R.E., Jones, A., Nighot, P., Pain, D.J. and Prakash, V. 2004. Diclofenac poisoning is widespread in declining vulture populations across the Indian subcontinent. Proceedings of the Royal Society of London Series B 271, S458-S460.

Swarup, D., Patra, R. C., Prakash, V., Cuthbert, R., Das, D., Avari, P., Pain, D. J., Green, R. E., Sharma, A. K., Saini, M., Das, D. and Taggart, M. 2007. The safety of meloxicam to critically endangered Gyps vultures and other scavenging birds in India. Animal Conservervation, 10: 192-198. 